Pswarayi, I. Z., R. D. Barnes, J. S. Birks and P. J. KANOWSKI (1997): Genotype-environment interaction in a population of Pinus elliottii Engelm. var. elliottii. Silvae Genetica 46: 35-40.

Rehfeldt, G. E., N. M. Tchebakova and L. K. Barnhardt (1999): Efficacy of climate transfer functions: introduction of Eurasian populations of Larix into Alberta. Can. J. For. Res. 29: 1660-1668.

Schmidtling, R. C. (2001): Southern pine seed sources. Gen. Tech. Rep. SRS-XX. Asheville, NC: USDA, Forest Service, Southern Research Station. 25pp.

UYeKI, H. (1928): On the physiognomy of Pinus densiflora growing in Korea and silvicultural treatment for its improvement. Bull. of the Agr. and For. Coll. Suwon. Korea. 263pp.

ViANA, J. M. S. and C. D. CRUZ (2002): Analysis of stability and adaptability through different models of line regression. Cienc. agrotec. Lavras 26: 455-462.
XU, P., C. C. YING and Y. A. EL-Kassaby (2000): Multivariance analyses of causal correlation between growth and climate in Sitka spruce. Silvae Genetica 49: 257-263.

YEISER, J. L., J. P. VAN BUITENEN and W. LOWE (1981): Genotype $\mathrm{x}$ environment interactions and seed movements for loblolly pine in the western gulf region. Silvae Genetica 30: 196-200.

Yeiser, J. L., W. Lowe and J. P. van BuiJTENEN (2001): Stability and seed movement for loblolly pine in the western gulf region. Silvae Genetica 50: 81-88.

YIM, K. B. and K. J. LEE (1979): The variation of natural population of Pinus densiflora S. et Z. in Korea (IX) needle and wood characteristics of six populations. J. Kor. For. Soc. 44: 1-25.

\title{
Mixed Mating With Preferential Outcrossing in Acacia saligna (Labill.) H. Wendl. (Leguminosae: Mimosoideae)
}

\author{
By N. GeORGE ${ }^{1,3), *)}$, M. ByrnE ${ }^{2,3)}$ and G. YAN ${ }^{1)}$
}

(Received $15^{\text {th }}$ November 2006)

\begin{abstract}
Acacia saligna is being developed as an agroforestry crop for the southern agricultural regions of Australia. This study investigated the breeding system of A. saligna to generate basic knowledge for breeding and utilization of the species. Allozyme markers were used to investigate the mating system of four populations of the species. All the populations had high outcrossing rates, with a mean multilocus outcrossing rate of 0.91 . The implications of a highly outcrossed mating system to the utilization of $A$. saligna are discussed.
\end{abstract}

Key words: Acacia saligna, agroforestry, mating system, high outcrossing.

\section{Introduction}

The Acacia genus comprises over 1500 species with the greatest species diversity, approximately 955

\footnotetext{
1) School of Plant Biology, Faculty of Natural and Agricultural Sciences, The University of Western Australia, 35 Stirling Highway, Crawley, WA 6009, Australia.

$\left.{ }^{2}\right)$ Science Division, Department of Conservation and Land Management, Locked Bag 104, Bentley Delivery Centre, WA 6983, Australia.

$\left.{ }^{3}\right)$ Co-operative Research Centre for the Plant-based Management of Dryland Salinity, The University of Western Australia, 35 Stirling Highway, Crawley, WA 6009, Australia.

*) Corresponding Author. School of Plant Biology, Faculty of Natural and Agricultural Sciences, The University of Western Australia, 35 Stirling Highway, Crawley, WA 6009, Australia. Email: georgnicholas@gmail.com
}

species, being native to Australia (MASLIN et al., 2003). The majority of these species belong to the subgenus Phyllodineae (MASLIN et al., 2003). Many Acacia species have characteristics that make them suitable as crops, including the production of useful products such as timber, charcoal, panel board pulp, tannin and livestock feed and agronomically favourable characters like fast growth rates and tolerance to harsh environmental conditions (MASLIN and MCDonald, 2004). Consequently, there is interest in the potential for domestication of Australian Acacia as crops for low rainfall agroforestry in the agricultural regions of southern Australia.

An examination of 35 Australian Acacia found A. saligna (Labill.) H.L. Wendl. (subgenus Phyllodineae) to have good potential for utilization as a forage crop (MASLIN and McDonald, 2004). Acacia saligna is native to the south-west of Western Australian and is already used extensively around the world (MASLIN and McDonald, 2004). The species has many favourable characteristics but there is also variation in economically important traits, such as growth form, which may be problematic for utilization. This variation may have underlying genetic causes (GEORGE et al., 2007; GEORGE et al., 2006) so selection and breeding of more uniform improved cultivars of $A$. saligna could be utilized to enhance the value of the species as a forage crop.

The mating system of plants influences breeding methodology and agronomic practices (ALLARD, 1999; SImmonds and SmaRTT, 1999). Despite the large number 
of species comprising the subgenus Phyllodineae, reproductive biology has been examined in detail in only a limited number of Acacia species (KENRICK, 2003). The general characteristics of reproductive biology tend to be similar in all species of Acacia so far studied, but differences between species do exist (KENRICK, 2003; KENRICK and Knox, 1989a; Sedgley, 1989). For example, high outcrossing rates have been detected in A. melanoxylon R.Br. (MuONA et al., 1991), A. anfractuosa Maslin (CoAtes et al., 2006), A. auriculiformis A. Cunn. ex Benth. (Moran et al., 1989a), A. crassicarpa A. Cunn. ex Benth. (MorAN et al., 1989a) and in some populations of A. mangium Willd. (BUTCHER et al., 1999). In contrast, the rare and restricted species, A. sciophanes Maslin, showed high levels of selfing with a comparatively low outcrossing rate of 0.61 (COATES et al., 2006). High inbreeding, with an outcrossing rate of 0.3 , has also been detected in the Daintree population of $A$. mangium as well as a seed stand established with germplasm from the population (BUTCHER et al., 1999).

Self-incompatibility, generally assessed by comparing seed set following self- and cross-pollination, has also been widely reported for many species of Phyllodineae. Existing evidence suggests self incompatibility in Acacia could be the result of post-zygotic lethal genes (KENRICK, 2003). Self-incompatibility levels have been shown to be variable. Studies of $A$. retiondes Schltdl. (BERNHARDT et al., 1984; KenRICK and KNOX, 1985; KenRICK and KNOX, 1989b), A. myrtifolia (Sm.) Willd., A. pycnantha Benth., A. mearnsii De Wild. (KenRICK and KNOX, 1989b), A. decurrens Willd., A. mollissima (syn. A. mearnsii) (Moffett, 1956) and A. baileyana F. Muell. (MorgAN et al., 2002) have shown seed set from self-pollination to be only 3 to $27 \%$ of that arising from cross-pollination. In contrast, seed set following self-pollination in A. paradoxa D.C. and A. ulicifolia (Salisb.) Court was 82 to $95 \%$ of that arising from cross-pollination (KENRICK and KNOX, 1989b) indicating general self-compatibility in these species. It should be noted that the level of seed set following selfing was variable in $A$. retinodes, A. mearnsii and A. mangium (Butcher et al., 1999; KENRICK and KNOX, 1989b).

There are no published accounts of the mating system of $A$. saligna, therefore the details of the mating system from a number a populations should be determined before domestication is undertaken. Analysis of progeny arrays using allozymes is a rapid and proven method for studying mating systems (ZEIDLER, 2000). This paper aims to characterise the mating system of A. saligna through analysis of allozyme variation in progeny arrays. It is hypothesised that the species will exhibit high outcrossing rates and self-incompatibility similar to other Acacia from the same subgenus.

\section{Materials and Methods}

Seeds were collected from six natural populations of A. saligna covering the four variants that have been identified in the species (MASLIN and MCDONALD, 2004) (Table 1). Seeds were also collected from a revegetation site (named Capel in this study) where a number of provenances were believed to be planted. The source of seeds used in the Capel plantation was unknown and the morphological variants were unable to be unambiguously identified.

At each population a large sample of pods (in excess of 100 per tree equating to approximately 400 seeds) were collected from throughout the canopy of 10-15 trees spaced at least 10 metres apart. This spatial sampling regime was chosen to accommodate the distribution of plants in the populations, which often covered less than $100-200 \mathrm{~m}$. Seed-set was found to be variable both within and between populations of A. saligna, which limited the number of populations available for sampling.

The seeds from each tree were dried, cleaned, bulked and stored at room temperature. To promote germination seeds were "nicked" using a scalpel and placed on moistened sponges in petri-dishes until they had a root radical 5 to $10 \mathrm{~mm}$ long. Germination within families was inconsistent, so individual seedlings were harvested and frozen in liquid nitrogen until sufficient progeny were available for assay. Whole seedlings were homogenized in Eppendorf tubes in $150 \mu \mathrm{l}$ of cold extraction buffer (50 mM boric acid pH 9, $0.5 \mathrm{mM}$ PVP-40, trace dithiothreitol). The homogenate was microfuged for 5 to 10 seconds to remove cell debris and $12 \mu \mathrm{l}$ of the supernatant was loaded onto cellulose acetate plates (Helena Laboratories Corp.). Electrophoresis was conducted according to the method described by COATES (1988). Plates were subjected to electrophoresis at $200 \mathrm{~V}$ for 35-50 min, depending on the isozyme system being tested, with running buffer TEM (80 mM Tris, $1 \mathrm{mM}$ EDTA, $1 \mathrm{mM} \mathrm{MgCl}_{2}$ ) or Tris (100 mM Tris). The isozyme phenotypes were interpreted genetically and scored as such. Scoring of genotypes within families was checked to ensure one putative maternal allele was present in each offspring and no more than two different homozygotes were present.

The following isozyme systems were tested to assay mating system parameters in A. saligna: AAT (aspartate aminotransferase EC 2.6.1.1), ACP (acid phosphatase EC 3.1.3.2), ADH (alcohol dehydrogenase EC 1.1.1.2), AK (adenylate kinase EC 2.7.4.3), EST- $\beta$ (esterase EC 3.1.1.-), FUM (fumarate hydratase EC 4.2.1.2), GDH (glutamate dehydrogenase EC 1.4.1.3), G6PD (glucose-6phosphate dehydrogenase EC 1.1.1.49), IDH (isocitrate

Table 1. - The populations of Acacia saligna, which were used in this study. Variant names refer to the informal variants described by MASLIN and MCDONALD (2004).

\begin{tabular}{lcclccc}
\hline Population Name & Lat E & Long. S & Subspecies & No. of mother trees & No. of progeny & No. of systems \\
\hline & & & & & & \\
Leschenault & 331304 & 1154136 & stolonifera & 15 & 387 & 178 \\
Tweed Road & 340006 & 1161308 & prinescens & 10 & 304 & 2 \\
Moore Rivet & 310354 & 1153310 & lindlevi & 14 & 299 & 4 \\
Capel & 333711 & 1152704 & Multiple provenances & 15 & & \\
\hline
\end{tabular}


dehydrogenase EC 1.1.1.42), LAP (leucyl aminopeptidase EC 3.4.11.1), LDH (L-lactate dehydrogenase EC 1.1.1.27), $\mathrm{MDH}$ (malate dehydrogenase EC 1.1.1.37), ME (malate dehydrogenase EC 1.1.1.40), MR (menadione reductase EC 1.6.5.2), PGD (phosphogluconate dehydrogenase EC 1.1.1.44), PGI (phosphoglucose isomerase E.C. 5.3.1.9), PGM (phosphoglucomutase EC 5.4.2.2) and SDH (shikimic dehydrogenase EC 1.1.1.25).

The multilocus genotypes based on allozymes were used to estimate mating system parameters. Maternal genotypes were inferred from the progeny arrays by the maximum likelihood method of BROWN and ALLARD (1970). For each population the multilocus population outcrossing rate (tm), the single locus population outcrossing rate (ts), the correlation of paternity ( $\mathrm{rp}$ ) and the correlation of selfing among families (rs) were calculated with the program MLTR using the Newton-Raphson numerical method (RITLAND, 2002). Wright's fixation index for the progeny arrays, and estimated maternal genotypes, was calculated using POPGENE (YEH et al., 1997).

Mating system estimates based on different loci may be correlated if those loci show linkage disequilibrium. To test for associations between locus pairs Burrows' composite measure of linkage disequilibrium was calcu- lated for all possible pairs of loci within populations by $\chi^{2}$ tests for significance according to WEIR (1990) using POPGENE (YEH et al., 1997). Where linkage disequilibrium was detected mating system analysis was performed with and without the affected loci for comparison.

Lack of significance between the estimated mating system parameters was determined by the presence of overlapping standard errors. Significant differences between pollen and ovule allelic frequencies were determined by calculation of the $95 \%$ confidence intervals for the data. The confidence intervals were calculated via the central limit theorem using the mean and standard error values for the allelic frequencies. It was assumed that the values were normally distributed. Significant differences were assigned where the confidence intervals did not overlap.

\section{Results}

Enzyme activity, in the form of banding, was resolved for all the isozyme systems and populations tested. However, the majority of systems exhibited either no polymorphisms or only one or two polymorphic individuals out of the total progeny sampled. Only five systems

Table 2. - Allele frequencies for maternal parents and pollen pools in sampled populations of Acacia saligna.

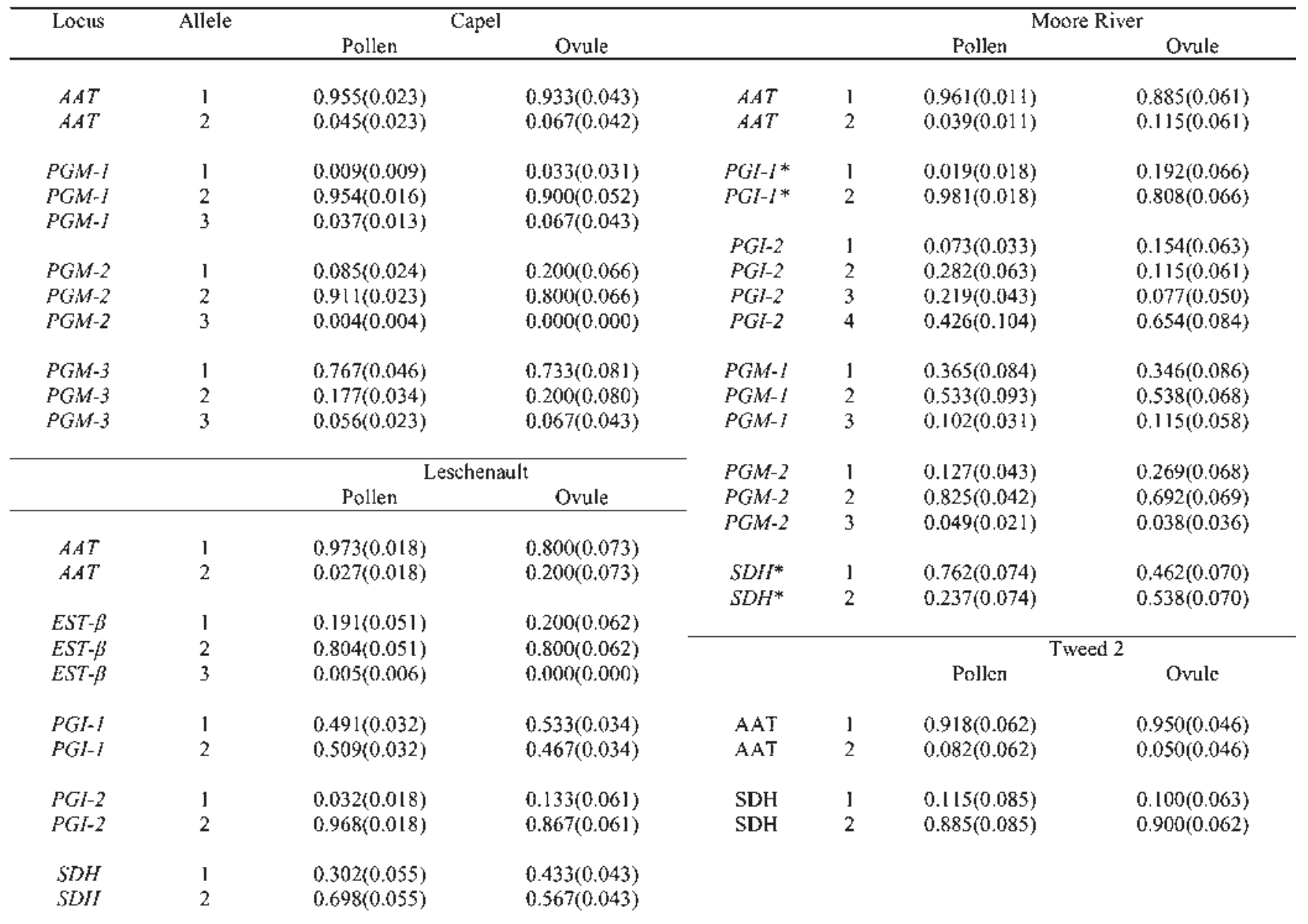

* Indicates significant differences between the pollen and ovule allelic frequencies at the $95 \%$ level. Standard errors are listed in parenthesis. 
(AAT, EST- $\beta$, PGI, PGM and SDH) produced sufficient polymorphism within seed crops to enable calculation of mating system parameters.

Only four of the seven populations, Moore River, Leschenault and Capel, exhibited polymorphisms. The Tweed River population was polymorphic at only two loci, which will reduce the accuracy with which the mating system parameters were estimated in this population (RITLAND, 2002). The remaining populations showed no useful allozyme polymorphisms. Therefore mating system parameters were determined for four populations, three natural populations and the planted population at Capel.

There was some banding complexity in the PGM system of the Moore River population. The general banding pattern was concordant with a monomeric enzyme although a small number of individuals exhibited extra bands that were intermediate between the PGM-1 and PGM-2 loci. These bands were interpreted as either post-translational modification or interlocus heterodimers (ZEIDLER, 2000) and were therefore not scored as alleles.

The estimate of Burrows' composite linkage disequilibrium indicated significant disequilibrium between loci in the Moore River and Capel populations. When mating system parameters were estimated with and without the affected loci, however, no significant difference was found between the results obtained from different analyses, and therefore all the loci were included in the final analysis. There were significant differences between the pollen and ovule allelic frequencies for the loci PGI-1 and SDH-1in the Moore River population (Table 2). This indicates that biparental inbreeding may be occurring in this population.

All populations showed high to very high outcrossing (Table 3). The multilocus population outcrossing rate $(\mathrm{tm})$ and single-locus outcrossing rate $(\mathrm{ts})$ varied from 0.804 to 0.998 and 0.765 to 0.999 respectively. The Leschenault population had the highest estimate of outcrossing, which was significantly greater than 1 . This has been observed in some other studies, including those on Acacia species (MANDAL and ENNOS, 1995; MORAN et al., 1989b). Six individuals in the Leschenault population had the same multilocus genotype making it possible that sampling across clones led to the overestimate. However, removing all but one of these families made no difference to estimates of mating system parameters. The outcrossing estimate for the population was there- fore interpreted as being truncated at 1 . Other than this the difference between the outcrossing rates among populations was not significant. The outcrossing rate in the Tweed River population was lower than in the other populations and the standard error was very high. This is probably due to the limited number of polymorphic loci assayed in this population.

The difference between the multi- and single-locus rate (tm-ts), which is an indicator of biparental inbreeding (RITLAND, 2002), varied from 0.000 to 0.080 , and the mean value was 0.036 . According to this measure the populations showed little evidence of biparental inbreeding, except for the Moore River population where biparental inbreeding was only marginally significantly different from zero. An alternative estimate of biparental inbreeding can be made using the correlation of selfing among loci ( $\mathrm{rs}$ ), where $\mathrm{rs}$ is the fraction of inbreeding due to uniparental inbreeding, and $1-\mathrm{rs}$ is the fraction of inbreeding due to biparental inbreeding (RITLAND, 2002). The mean correlation of selfing was low (0.41) in all populations, although the standard errors were very large. The low correlation of selfing suggests that the inbreeding observed was due to biparental inbreeding rather than selfing. This value is higher than the estimate of tm-ts, as expected since tm-ts is considered to underestimate biparental inbreeding (RITLAND, 2002).

The correlation of outcrossed paternity (the fraction of siblings with the same paternity) within progeny arrays varied from 0.032 to 0.302 for multilocus estimates (rpm) and -0.019 to 0.262 for single locus estimates (rps). With the exception of Tweed Road, where correlated paternity was negligible, the multilocus correlated paternity values in the populations were low to moderate and significantly greater than zero, indicating a small amount of correlated mating. The single versus multilocus correlated paternity (rps - rpm) was not significantly different from zero in any of the populations, indicating no effect of population substructure on the male similarity between outcrosses. The mean parental fixation indices were negative, with a mean of -0.254 . The Moore River and Leschenault populations showed large negative values but the standard errors were also high. The mean fixation indices for the progeny (Fprog) were positive but not significantly different from zero in any of the populations. Examination of heterozygosity in estimated paternal genotypes and the progeny arrays showed that the number of heterozygous individuals,

Table 3. - Mating system estimates for the four populations of Acacia saligna. $F_{\text {par }}$, Wright's single-locus inbreeding coefficient of the maternal parents. $F_{\text {prog }}$, Wright's single-locus inbreeding coefficient of the progeny. $t_{m}$, multilocus population outcrossing rate. $t_{s}$, single-locus population outcrossing rate. $t_{m}-t_{s}$, indicator of biparental inbreeding, $r_{p m}$, multilocus correlation of paternity, $r_{p s}$, single-locus correlation of paternity, and $r_{s}$, the correlation of selfing among loci. Standard errors in parenthesis. The $t_{m}$ and $t_{s}$ values for Leschenault have been truncated at 1.0 .

\begin{tabular}{|c|c|c|c|c|c|c|c|c|c|}
\hline Population & $F_{\mathrm{Par}}$ & $F_{\text {prrg }}$ & $t_{m}$ & $t_{s}$ & $t_{m-t_{s}}$ & $S_{\mathrm{FrOH}}$ & $r_{p s}$ & $r_{p 18}=r_{p m}$ & $r_{s}$ \\
\hline Tweed Road & $-0.082(0.034)$ & $0.208(0.317)$ & $0.804(0.253)$ & $0.765(0.266)$ & $0.039(0.019)$ & $0.032(0.110)$ & $-0.019(0.113)$ & $0.050(0.038)$ & $0.001(0.453)$ \\
\hline Moore River & $-0.259(0.175)$ & $0.216(0.285)$ & $0.875(0.044)$ & $0.796(0.073)$ & $0.080(0.037)$ & $0.302(0.110)$ & $0.262(0.134)$ & $0.040(0.053)$ & $0.063(0.177)$ \\
\hline Leschenault & $-0.490(0.257)$ & $0.019(0.128)$ & $1.000(0055)$ & $1.00000046)$ & $0.000(0.023)$ & $0.151(0.059)$ & $0.179(0.054)$ & $-0.027(0.022)$ & $0.097(0-393)$ \\
\hline Capel & $-0.079(0.118)$ & $0.099(0.163)$ & $0.920(0.052)$ & $0.888(0.062)$ & $0.032(0.02 B)$ & $0.106(0.051)$ & $0.070(0.034)$ & $0.036(0.029)$ & $0.001(0.362)$ \\
\hline Mean & -0.227 & 0.135 & 0.900 & 0.862 & 0.038 & 0.148 & 0.132 & 0.038 & 0.041 \\
\hline
\end{tabular}


and the number of heterozygous loci, was greater in the maternal population compared to the progeny arrays. The proportion of individuals with multiple heterozygous loci was also higher in the Leschenault and Moore River populations than in the other populations. Inspection of the gene frequency estimates for populations showed that the SDH-1 and PGI-1 loci in the Leschenault population had higher proportion of heterozygosity compared with loci in the other populations.

\section{Discussion}

All the populations of $A$. saligna examined in this study, including the planted population at Capel, showed high outcrossing rates. The mean multilocus outcrossing rate across the populations was 0.91 . This level of outcrossing is marginally lower than that found in many Acacia species (CoATES, 1988; MANDAL and EnNos, 1995; MorAn et al., 1989b; MuONA et al., 1991), but is similar to that found in A. melanoxylon (MUONA et al., 1991) and the Western Australian species A. anfractuosa (COATEs et al., 2006). This level of outcrossing indicates that $A$. saligna has a mixed mating system (preferential outcrossing but with some level of selfing).

The high outcrossing rates in A. saligna populations are potentially due to genetically-induced self incompatibility. As discussed, studies of other Acacia have found evidence that self incompatibility in some species may be the result of post-zygotic lethal genes (KENRICK, 2003). It can be hypothesised that $A$. saligna may therefore also posses a system of such genes. In addition, the most significant method of pollen dispersal in Acacia species is via animal visitation to flowers, with insects being the most prevalent pollen vectors (KENRICK, 2003). The primary insect pollen vectors for species in the genus, including A. saligna, are Apoidea (Hymenoptera), and to a lesser extent Syrphidae (Diptera) (BERNHARDT, 1989; George, 2005; STONE et al., 2003). Insects from these groups are strong fliers that actively forage between plants (TIOA, 1991). It seems likely that this behaviour will facilitate the broad dispersal of $A$. saligna pollen and consequently facilitate outcrossing.

Acacia saligna frequently occurs in small stands, which might be expected to lead to biparental inbreeding and correlated paternity. The level of inbreeding detected in this study was low, but the correlation of selfing estimates suggest the majority of the inbreeding that was detected was due to biparental inbreeding rather than selfing, although the large standard errors indicate high variance among mothers. Some evidence of correlated paternity was found and was similar to that detected in two other Western Australian species, A. sciophanes and $A$. anfractuosa (COATES et al., 2006). In a study of A. melanoxylon, MuONA et al. (1991) determined correlated paternity across hierarchical levels and found the proportion of full-sib-pairs to be 0.6 to 1 within pods, 0.35 within flower-heads and $0.1-0.2$ between seeds within a tree. In the present study the assayed seeds were randomly selected from a bulked sample taken within a tree, so pod and flower-head hierarchical levels were not examined. However, the correlated paternity values detected here for $A$. saligna are similar to the within-tree values obtained in the study of $A$. melanoxylon (MUONA et al., 1991). Thus the level of correlated paternity detected here is probably related to the floral biology of Acacia rather than small population size or other ecological factors.

Improvement through selection in outcrossed species is typically difficult because of high levels of segregation and constantly changing arrays of differing alleles and multilocus genotypes between generations (ALLARD, 1999). In these types of plants genotypes will either be eliminated before their agricultural potential can be assessed, or selected genotypes may be lost in subsequent generations as gains from breeding are diluted through outcrossing (ALLARD, 1999; ELLSTRAND et al., 1999). Attempts to fix traits through inbreeding usually encounter barriers to selfing, and if selfing is achieved progeny of predominant outcrossers typically show reduced fitness (ALLARD, 1999).

Studies have found evidence that inbreeding is the cause of reduced vigour in populations of other Acacia species (BuTCHER et al., 1999; HARWOOD et al., 2004). For example, the poor performance of the Subanjeriji Seed Stand of $A$. mangium has been linked to the high level of selfing in the stand (BUTCHER et al., 1999). Evidence for selection against inbreeding was detected in this study in the form of differences in heterozygosity between parental and progeny populations. This is indicative of selection between the seed and adult stages in the life cycle of the plants (NEEL et al., 2001; SAMPSON et al., 1989). Generational difference in heterozygosity is common in Acacia (COATES et al., 2006) and selection against inbreeding is evident where selfed progeny show lowered viability and reduced vigour (BUTCHER et al., 1999; KENRICK and Knox, 1989a; MofFetT, 1956).

A breeding method suitable for outcrossing species, potentially involving improvement though mass selection, would therefore probably be appropriate for A. saligna (Allard, 1999; PoEhlman, 1983). To prevent the dilution of breeding gains by out-crossing, superior genotypes produced by breeding could be preserved via vegetative propagation by exploiting the species suckering potential (MASLIN and MCDONALD, 2004) or via tissue culture of shoot-tips (BARAKAT and EL-LAKANY, 1992).

Predominant outcrossing also suggests there is a likelihood of geneflow between plantations and wild populations of A. saligna. This could have negative impacts on the viability of wild populations if the gene pool of the plantation is differentiated through selection or use of non-local germplasm. Negative impacts from out-crossing could arise through dilution of local adaptation or disruption of co-adapted gene complexes (TEMPLETON, 1986) or the introduction of non-adaptive genes (POTTS et al., 2003). Gene flow from wild populations to breeding populations could also be detrimental as it would dilute the genetic gains made through breeding. It will therefore be important to determine the potential distance across which gene flow can occur in A. saligna. This will enable assessment of the risk posed by genetic pollution to both plantations and natural populations, and potential methods to reduce the risk such as the use of buffer zones. 
Variation between populations in the allozyme systems that exhibited polymorphism, and the significant differences in allele frequencies at all loci, suggests there is genetic differentiation within A. saligna. This genetic differentiation is most likely indicative of intraspecifc differentiation that has previously been detected using RFLP markers (GEORGE et al., 2006). The low level of allozyme variation detected in this study is in contrast to the moderate levels of polymorphism observed within populations of A. saligna using RFLP markers (GEORGE et al., 2006). This result is similar to studies of genetic diversity in A. mangium that showed very low isozyme variation but greater RFLP variation (BUTCHER et al., 1998; MorAn et al., 1989a).

\section{Acknowledgments}

We thank JANe SAmpson, CAROLE ElliotT and BronWYN MACDONALD at the CALM Science laboratories for their assistance with the analysis; SALLY THOMPSON, CHRIS JONES and LEIDA WILLIAMS for their assistance in the field; and Frank Doyle and Iluka Resources Ltd for allowing samples to be taken from their land.

\section{References}

AllaRD, R. W. (1999): 'Principles of Plant Breeding.' (John Wiley and Sons: New York).

Angell, K. and R. Glencross (1993): Tagasaste and Acacia saligna establishment using bare-rooted seedlings. pp. 8. Western Australian Department of Agriculture Bulletin 4262.

BARAKAT, M. N. and M. H. EL-LAKANY (1992): Clonal propagation of Acacia saligna by shoot tip culture. Euphytica 59: 103-107.

Bernhardt, P., J. Kenrick and B. R. Knox (1984): Pollination biology and the breeding system of Acacia retinodes (Leguminosae: Mimosoideae). Annals of the Missouri Botanical Gardens 71: 17-29.

BeRnhardT, P. (1989): The floral ecology of Australia Acacia. In: 'Advances in Legume Biology: proceedings of the Second International Legume Conference, St. Louis, Missouri, 23-27 June 1986, held under the auspices of the Missouri Botanical Garden and the Royal Botanic Gardens, Kew'. (Eds C. H. STIRTon and J. L. ZARUCCHI) pp. 263-281. (Monographs in Systematic Botany from the Missouri Botanic Garden).

Brown, A. H. D. and R. W. Allard (1970): Estimation of the mating system in open pollinated maize populations using isozyme polymorphisms. Genetics 66: 133-145.

Butcher, P. A., J. C. Glaubitz and G. F. Moran (1999): Applications for microsatellite markers in the domestication and conservation of forest trees. Forest Genetic Resources Information 27: 34-42.

Butcher, P. A., G. A. Moran and H. D. Perkins (1998): RFLP diversity in the nuclear genome of Acacia mangium. Heredity 81: 205-213.

CoATes, D., G. Tischler and J. A. McComb (2006): Genetic variation and the mating system in the rare ghost wattle, Acacia sciophanes compared with its common sister species Acacia anfractuosa (Mimosaceae). Conservation Genetics. In press.

CoATES, D. J. (1988): Genetic diversity and population genetic structure in the rare Chittering Grass Wattle, Acacia anomala Court. Australian Journal of Botany 36: $273-286$.
Ellstrand, N. C., H. C. Prentice and J. F. Hancock (1999): Gene flow and introgression from domesticated plants into their wild relatives. Annual Review Ecology and Systematics 30: 539-563.

George, N., D. Henry, G. YAn and M. Byrne (2007): Variability in feed quality between populations of Acacia saligna (Labill.) H. Wendl. (Mimosoideae)-implications for domestication. Animal Feed Science and Technology 136: $109-127$.

George, N., M. Byrne, B. Maslin and G. YAN (2006): Genetic differentiation among morphological variants of Acacia saligna (Mimosaceae). Tree Genetics and Genomes 2: 109-119.

GEORGE, N. (2005): Koojong (Acacia saligna), a species with potential as a perennial forage for dryland salinity management - genetic variation, feed quality and reproductive biology. $\mathrm{PhD}$ Thesis. The University of Western Australia. p 225.

Harwood, C. E., H. H. Thinh, T. H. Quang, P. A. Butcher and E. R. Williams (2004): The effect of inbreeding on early growth of Acacia mangium in Vietnam. Silvae Genetica 53: 65-69.

KENRICK, J. (2003): Review of pollen-pistil interactions and their relevance to the reproductive biology of Acacia. Australian Systematic Botany 16: 119-130.

KENRICK, J. and B. R. KNOX (1985): Self-incompatibility in the nitrogen-fixing tree, Acacia retinodes: quantitative cytology of pollen tube growth. Theoretical and Applied Genetics 69: 481-488.

KENRICK, J. and B. R. KNox (1989a): Pollen-pistil interactions in Leguminosae (Mimosoideae). In: 'Advances in Legume Biology: Proceedings of the Second International Legume Conference, St. Louis, Missouri, 23-27 June 1986, held under the auspices of the Missouri Botanical Garden and the Royal Botanic Gardens, Kew'. (Ed. J. L. ZARUCCHI) pp. 127-153. Monographs in Systematic Botany from the Missouri Botanic Garden.

KENRICK, J. and B. R. KNox (1989b): Quantitative analysis of self-incompatibility in trees of seven species of Acacia. Journal of Heredity 80: 240-245.

MANDAL, A. K. and R. A. EnNos (1995): Mating system analysis in a natural population of Acacia nilotica subspecies kraussiana. Forest Ecology and Management 79: $235-240$.

Maslin, B., J. T. Miller and S. D. Seigler (2003): Overview of the generic status of Acacia (Leguminosae: Mimosoideae). Australian Systematic Botany 16: 1-18.

MASLIN, B. R. and M. W. MCDonALD (2004): 'AcaciaSearch: Evaluation of Acacia as a Woody Crop Option for Southern Australia.' Rural Industries Research and Development Corporation, Canberra.

Moffett, A. A. (1956): Genetical studies in acacias. 1. The estimation of natural crossing in Black Wattle. Heredity 10: $57-67$.

Moran, G. F., O. Muona and J. C. Bell (1989a): Acacia mangium: A tropical forest tree of the coastal lowlands with low genetic diversity. Evolution 43: 231-235.

Moran, G. F., O. Muona and J. C. Bell (1989b): Breeding system and genetic diversity in Acacia auriculiformis and A. crassicarpa. Biotropica 21: 250-256.

Morgan, A., S. M. CARThew and M. Sedgley (2002): Breeding system, reproductive efficiency and weed potential of Acacia baileyana. Australian Journal of Botany 50: 357-364.

Muona, O., G. F. Moran and J. C. Bell (1991): Hierarchical patterns of correlated mating in Acacia melanoxylon. Genetics 127: 619-626. 
Neel, M. C., J. Ross-Ibarra and N. C. Ellstrand (2001): Implication of mating patterns for conservation or the endangered plant Eriogonoum ovalifolium var. vineum (Polygonaceae). American Journal of Botany 88: 1214-1222.

Poenlman, J. M. (1983): 'Breeding Field Crops.' The AVI Publishing Company Inc.: Westport, Connecticut.

Potts, B. M., R. C. Barbour, A. B. Hingston and R. E. VAILLANCOURT (2003): Genetic pollution of native Eucalypt gene pools - identifying the risks. Australian Journal of Botany 51: 1-25.

RitLAND, K. (2002): Extensions of models for the estimation of mating systems using $\mathrm{n}$ independent loci. Heredity 88: 221-228.

SAmpson, J. F., S. D. Hopper and S. H. JAmes (1989): The mating system and population genetic structure in a bird-pollinated mallee, Eucalyptus rhodantha. Heredity 63: 383-393.

SedGley, M. (1989): Acacia. In: 'Handbook of Flowering'. (Ed. A. H. Halevy) pp. 1-11. CRC Press: Boca Raton, Florida.
Simmonds, N. W. and J. SMARTT (1999): 'Principles of Crop Improvement.' Blackwell Science Ltd.: Carlton, Victoria.

Stone, G. N., N. E. Raine, M. Prescott and P. G. WILLMER (2003) Pollination ecology of acacias (Fabaceae, Mimosoideae). Australian Systematic Botany 16: 103-118.

Templeton, A. R. (1986): Coadaptation and outbreeding depression. In: 'Conservation Biology. The Science of Scarcity and Diversity’. (Ed. M. E. Soule) pp. 105-116. Sinauer Associates Inc, Sunderland.

TIOA (1991): 'The Insects of Australia.' (Melbourne University Press: Carlton, Victoria).

WeIR, B. S. (1990): ‘Genetic Data Analysis.' Sinauer Associates Inc.: Sunderland.

YeH, F. C., H.-Y. YANG, B. J. Boyle, Z.-H. Ye and J. X. MAO (1997): POPGENE, the user-friendly shareware for population genetic analysis. Molecular Biology and Biotechnology Centre, University of Alberta: Canada.

ZEIDLER, M. (2000): Electrophoretic analysis of plant isozymes. Biologica 38: 7-16.

\title{
Genetics of Shrinkage in Juvenile Trees of Pinus radiata D. Don From Two Test Sites in Australia
}

\author{
By W. J. Gapare $\left.{ }^{*}\right), 1$, M. Ivković(1), M. B. Powell ${ }^{2)}$, T. A. $\mathrm{MCRAE}^{2)}$ and H. X. Wu ${ }^{1)}$
}

(Received $22^{\text {th }}$ November 2006)

\begin{abstract}
To examine the genetic control of wood shrinkage (radial, tangential and longitudinal) in juvenile wood of radiata pine (Pinus radiata D. Don), we assessed samples collected at breast height in two related progeny tests of age 8 and 9 years, established at two different sites in Australia. Green to oven-dry tangential and radial shrinkage for the outer-rings was similar at both sites. Similarly, mean longitudinal shrinkage for the outer-rings was similar at both sites $(0.3 \%$, ranging from 0.1 to 1.9 at Flynn and $0.4 \%$, ranging from 0.02 to 1.6 , at Kromelite). Mean longitudinal shrinkage for the inner-rings was 4 times greater than that of the outerrings at both sites. The magnitude of the gradient of longitudinal shrinkage from pith to bark (0.001 to $2.9 \%)$ is large enough to cause distortion problems including twist and warp, during drying of sawn boards. These values also suggest that shrinkage in the juvenile core of radiata pine is of major economic importance and therefore should be improved either through genetics or silviculture.
\end{abstract}

1) Ensis ${ }^{3)}$, CSIRO Forestry and Forest Products, P. O. Box E4008, Canberra, ACT 2604, Australia.

2) Southern Tree Breeding Association Inc, P. O. Box 1811 Mt. Gambier, SA 5290, Australia.

3) Ensis is a joint venture between CSIRO FFP P/L and Scion Australasia P/L.

*) Corresponding author: Washington.Gapare@ensisj.com.
Individual-tree narrow-sense individual heritability for tangential and radial shrinkage in the outer-rings (4-6) was moderate at Flynn $(0.24 \pm 0.09$ and $0.26 \pm 0.07$, respectively). There was a lack of significant genetic variation for longitudinal shrinkage in the outer-rings but significant genetic control for the inner-rings (1-2) $\left(h^{2}=0.26 \pm 0.07\right)$. More samples per family are required to detect significant genetic variation for shrinkage traits than other traits due to higher background variation in sampling and measuring shrinkage traits relative to other wood quality traits such as density, microfibril angle (MfA), spiral grain and modulus of elasticity (MoE).

Key words: Pinus radiata, juvenile wood, distortion, shrinkage, genetic control.

\section{Introduction}

Extensive literature is available on the occurrence and limitations of juvenile wood in fast growing conifers, including Pinus radiata D. Don (e.g., Cown et al., 1992; ZoBel and SPRAGUE, 1998; Cown and VAN WYK, 2004). In radiata pine, most of the literature deals with genetic variation in wood density components (e.g., ring density, ring width, earlywood density, latewood density, modulus of elasticity $(\mathrm{MoE})$ ) with tree age (KUMAR and LEE, 2002; KuMAR, 2004; Li and WU, 2005; Wu et al., 2007). Such information may be insufficient for making practi- 